\title{
STRATEGI PENGENALAN POTENSI ANAK
}

\author{
Makmun Zahruddin \\ STAINurEl-Ghasy, makmun_zabruddin@gmail.com
}

Diterima: 8 Maret $2018 \quad$ Direvisi: 28 November $2018 \quad$ Diterbitkan: 30 Desember 2018

\begin{abstract}
Basically, humans have two great abilities, namely the actual ability and potential ability. Actual abilities are abilities that exist today, abilities that have already been seen. This can be seen (in part) for example from IQ scores, TOEFL scores, and academic scores. Potential abilities are abilities that have not yet been seen, abilities that have the opportunity to develop; Therefore to develop it requires stimulants from the environment (education, parents, teachers, nutrition), for example talents. This article tries to identify several potentials and how to identify them. To identify the potential is needed for teachers to understand their children by understanding the child's growth and developmental tasks at each stage. Ways to identify the potential of children can use two things, namely by identifying the child's talents and knowing their interests (child's personality). Children's talent can be identified from general abilities (intelligence), creativity, and motivation.
\end{abstract}

Keywords: Diagnosis, Potency, Kids.

\begin{abstract}
Abstrak
Pada dasarnya manusia memiliki dua kemampuan besar yaitu kemampuan aktual dan kemampuan potensial. Kemampuan aktual merupakan kemampuan yang ada saat ini, kemampuan yang telah nampak. Ini dapat dilibat (sebagian) misalnya dari skor IQ, skor TOEFL, dan nilai akademik. Kemampuan potensial merupakan kemampuan yang belum nampak, kemampuan yang memiliki kesempatan untuk berkembang; Oleh karenanya untuk mengembangkannya memerlukan stimulanstimulan dari lingkungan (pendidikan, orang tua, guru, nutrisi), misalya talenta. Artikel ini mencoba untuk mengidentifikasi beberapa potensi dan bagaimana cara untuk mengidentifikasinya. Untuk mengidenifikasi potensi diperlukan bagi para guru untuk memahami anak-anaknya yaitu dengan memahami pertumbuhan anak dan tugas-tugas perkembangan untuk setiap tahapannya. Cara untuk mengidentifikasi potensi anak dapat menggunakan dua hal yaitu dengan mengidentifikasi bakat anak dan mengetahui minatnya (kepribadian anak). Bakat anak dapat diidentifikasi dari kemampuan umum (inteligensi), kreativitas, dan motivasi.
\end{abstract}

Kata Kunci: Diagnosa, Potensi, Anak.

\section{PENDAHULUAN}

Kata 'potensi' merupakan sebuah kata yang sudah tidak asing lagi didengar di kalangan masyarakat kita, masyarakat awam sekalipun. Orang sering menggunakan istilah potensi ini untuk melihat atau menentukan berbagai hal seperti untuk melihat inteligensi (IQ), bakat, prestasi, dan sebagainya. ${ }^{1}$ Misalnya ketika ada anak yang memiliki kemampuan verbal yang fasih dan lancar maka tak urung anak itu akan dikatakan sebagai anak yang berpotensi; atau ketika melihat anak yang pandai

\footnotetext{
1 Saparinah Sadli (editor), 1986. Inteligensi, Bakat, dan Test IQ. Cetakan I. Jakarta: Gaya Favorit Press. Hal.10
} 
dalam prestasi akademiknya maka anak itu akan dikatakan sebagai anak yang berpotensi.

Pada dasarnya manusia memiliki dua kemampuan besar yaitu kemampuan aktual dan kemampuan potensial. Kemampuan aktual merupakan kemampuan yang ada saat ini, kemampuan yang sudah teraktualisasikan. Contohnya adalah skor IQ dan skor TOEFL. Skor IQ dan skor TOEFL ini dikatakan sebagai kemampuan aktual karena ada wujudnya yaitu angka-angka. Adapun kemampuan potensial merupakan kemampuan yang belum tergali, belum teraktualisasikan; kemampuan yang berwujud kemungkinan-kemungkinan. Misalnya bakat. Dikatakan sebagai kemampuan potensial karena bakat itu belum muncul, belum nyata, belum aktual. Untuk mengetahui bakat yang dimiliki seseorang, maka bakat itu harus digali, harus distimulan. Setelah digali atau distimulan maka bakatpun dapat diketahui, dan bila bakat sudah diketahui, maka wujud (aktualisasi) dari bakat itu tidak lagi disebut sebagai kemampuan potensial tetapi sebagai kemampuan aktual.

Untuk dapat mengetahui dan mengembangkan kemampuan potensial (potensi) anak maka potensi itu harus distimulan oleh lingkungannya, yang dalam hal ini adalah para pendidik khususnya orang tua. Bila para orang tua hendak mengembangkan potensi anaknya, maka orang tua harus dapat memahami diri anak terlebih dahulu.

\section{MEMAHAMI ANAK}

Hal penting sebelum mengadakan diagnosa terhadap potensi anak adalah bahwasannya orang tua sebagai pendidik harus memahami dulu tentang diri anaknya sendiri. Memahami diartikan sebagai mengetahui dan mengenali anak, misalnya mengetahui dan mengenali karakternya, mengetahui dan mengenali gaya belajarnya, mengetahui dan mengenali motivasi belajar mereka apakah atas dorongan sendiri (karena ingin sukses dalam belajar) atau atas dorongan orang tua, atau karena tergiur dengan iming-iming / hadiah dari nenekkakeknya, dan sebagainya. Dengan memahami anak maka akan memudahkan orang tua dalam menggali potensi-potensi yang dimilikinya.

Sebuah penelitian membuktikan bahwa aspek-aspek psikologis seperti minat, motivasi, suasana PAKEM (pembelajaran aman, kreatif, efektif, dan menyenangkan) memiliki peranan yang sangat penting terhadap kesuksesan pembelajaran. ${ }^{2}$ Aspek-aspek psikologis ini menyiratkan, betapa anak ingin dipahami betul oleh orang tua/pendidik, ingin diperlakukan secara manusiawi oleh pendidik. Karena ternyata dengan memahami aspek-aspek psikologis dari anak ini dapat membawa pada berhasilnya proses pembelajaran. Maka sudah seyogianya pendidik memahami berbagai hal yang berkaitan dengan anaknya dalam proses pembelajaran. Untuk memahami anak bisa dilakukan dengan berbagai cara, mulai dari bagaimana perkembangan anak baik perkembangan fisik, fisiologis, maupun psikologisnya dan tugastugas perkembangan apa yang harus dilakukan dalam setiap tahapnya.

\section{Perkembangan Anak}

Manusia akan mengalami sebuah proses perubahan menuju kemajuan yang disebut sebagai perkembangan atau pertumbuhan. Menurut para ahli psikologi perkembangan yang akan dialami oleh manusia meliputi: perkembangan fisik (sensorik-motorik), perkembangan kognitif, perkembangan sosio-emosional, perkembangan moral. ${ }^{3}$ Ini semua seyogianya harus difahami betul oleh para pendidik agar para pendidik dapat

2 Hand out mata kuliah Psikologi Inteligensi pada Program Pasca Sarjana Program Studi Psikologi UGM oleh Yapsir Gandhi Wirawan

3 Monks dkk., 1996. Psikologi Perkembangan Pengantar dalam Berbagai Pengembangannya. Jogjakarta: Gadjah Mada University Press. Hal. 34 
memperlakukan dengan tepat anak-anaknya. ${ }^{4}$ Semua jenis perkembangan -baik kognitif ataupun nonkognitif- ini dapat dijelaskan melalui tahaptahap perkembangan anak.

Perkembangan kemampuan anak usia 0 sampai 5 tahun (TK). Pada usia ini, anak berada dalam periode 'pra-operasional' yang dalam menyelesaikan persoalan ditempuh melalui tindakan nyata dengan jalan memanipulasi benda atau objek yang bersangkutan. Anak belum mampu untuk menyelesaikan persoalan melalui cara berfikir logik sistematik. Kemampuan mengolah informasi dari lingkungan belum cukup tinggi untuk dapat menghasilkan transformasi yang tepat. Demikian juga perkembangan moral anak masih berada pada tingkatan moralitas yang baku. Anak belum sampai pada pemilihan kaidah moral sendiri secara nalar. Perkembangan nilai dan sikap sangat dipengaruhi oleh situasi yang berlaku dalam keluarga. Nilai-nilai yang berlaku dalam keluarga akan diadopsi oleh anak dengan suasana dan lingkungan keluarga yang besar.

Perkembangan kemampuan anak usia 6 sampai 12 tahun (SD). Pada usia ini anak dalam periode operasional konkrit yang dalam menyelesaikan masalah sudah mulai ditempuh dengan berfikir, tidak lagi terlalu terikat pada keadaan nyata. Kemampuan mengolah informasi lingkungan sudah berkembang sehingga informasi yang dihasilkan sudah lebih sesuai dengan kenyataan. Demikian juga perkembangan moral anak sudah mulai beralih pada tingkatan moralitas yang fleksibel dalam rangka menuju ke arah pemilihan kaidah moral sendiri secara nalar. Perkembangan moral anak masa ini sangat dipengaruhi oleh kematangan intelektual dan interaksi dengan lingkungannya. Dorongan untuk keluar dari lingkungan rumah dan masuk kedalam

4 Maksud dari pemberian perlakuan yang tepat adalah bahwasannya pendidik dapat memberikan perlakuan kepada peserta didik sesuai dengan tahap perkembangannya. Lihat Santrock, 1997, Life Span Development, hal 231. kelompok sebaya mulai nampak dan semakin berkembang. Pertumbuhan fisik mendorong anak untuk memasuki permainan yang membutuhkan otot kuat.

Perkembangan kemampuan anak pada usia 13 sampai 15 tahun (SLTP). Pada usia ini anak memasuki tahap remaja, periode formal operasional yang dalam perkembangan cara berpikir mulai meningkat ke taraf lebih tinggi, abstrak dan rumit. Cara berpikir yang bersifat rasional, sistematik, dan eksploratif mulai berkembang pada tahap ini. Kecenderungan berpikir mereka mulai terarah pada hal-hal yang bersifat abstrak. Kemampuan mengolah informasi dari lingkungan sudah semakin berkembang.

Selain terdapat perkembangan kemampuan pada setiap tahap, dalam setiap tahap perkembangan ada juga yang disebut sebagai tugas perkembangan/tugas belajar. Tugas perkembangan atau sering disebut juga sebagai tugas belajar, merupakan tugas yang harus dilalui oleh setiap anak dalam setiap tahap perkembangannya. Bila tugastugas dalam setiap tahap perkembangan tidak dilakukan atau tidak dialami oleh anak, maka tugas lingkungan untuk terus menstimulasinya. Tugas perkembangan dalam setiap tahapnya meliputi beberapa hal. ${ }^{5}$

Tugas perkembangan tahap bayi dan kanakkanak meliputi: belajar memakan makanan keras, belajar mandiri dan berjalan, belajar berbicara, belajar mengendalikan pengeluaran benda-benda buangan dari tubuhnya, belajar membedakan jenis kelamin, mencapai kematangan untuk belajar membaca (mulai siap mengenali huruf, suku kata, dan kata-kata tertulis), belajar mengadakan hubungan emosional selain dengan keluarga inti, belajar membedakan yang baik dan buruk/benar dan salah.

5 Depdiknas, 2004. Tahap-tahap Perkembangan Peserta Didik, dalam Pedoman diagnostik Potensi Peserta Didik. Ditjen Dikdas Direktorat Pendidikan Lanjutan pertama, hal.4-5 
Tugas perkembangan tahap anak-anak; belajar keterampilan fisik, membina sikap yang sehat (positif) terhadap dirinya, belajar bergaul dengan teman-teman sebaya, belajar memainkan peran sesuai jenis kelamin, belajar mengembangkan dasar-dasar keterampilan membaca-menulisberhitung, mengembangkan konsep-konsep, mengembangkan kata hati-moral-skala nilai, mengembangkan sikap objektif, belajar mengembangkan kemerdekaan/kebebasan pribadi.

Tugas perkembangan tahap remaja:, mencapai pola hubungan baru yang lebih matang dengan teman sebaya, mencapai peranan sosial sesuai jenis kelamin, menerima kesatuan organorgan tubuh sesuai jenis kelamin, keinginan menerima dan mencapai tingkah laku sosial tertentu, mencapai kebebasan emosional dari orang tua dan orang dewasa lain, mempersiapkan diri untuk mencapai karir, mempersiapkan diri untuk memasuki dunia perkawinan, memperoleh seperangkat nilai dan sistem etika sebagai pedoman berperilaku.

Tugas perkembangan dewasa; mulai bekerja mencari nafkah, memilih pasangan hidup, mulai memasuki kehidupan berrumah tangga, belajar hidup bersama pasangan, mengelola tempat tinggal untuk keperluan rumah tangga, membesarkan anakanak, menerima tanggung jawab kewarganegaraan, menemukan kelompok sosial.

Tugas perkembangan tahap setengah baya; mencapai tanggung jawab sosial dan kewarganegaraan, membantu anak-anak yang berusia belasan tahun, mengembangkan aktifitas dan memanfaatkan waktu luang bersama orangorang dewasa lainnya, menghubungkan diri sedemikian rupa dengan pasangannya sebagai pribadi yang utuh, menerima dan menyesuaikan diri dengan perubahan-perubahan psikologis, mencapai dan melaksanakan penampilan yang memuaskan dalam karir, menyesuaikan diri dengan perikehidupan orang-orang yang berusia lanjut.
Tugas perkembangan tahap usia tua; menyesuaikan diri dengan menurunnya kekuatan dan kesehatan fisik, menyesuaikan diri dengan kondisi pensiun dan berkurangnya income, menyesuaikan diri dengan kematian pasangannya, membina hubungan yang tegas dengan orang seusia, membina pengaturan fisik sesuai kebutuhan, menyesuaikan diri dengan peranan-peranan sosial dengan cara yang luwes.

Pemahaman terhadap anak diperlukan dalam rangka membantu anak menjalani tugastugas perkembangan tersebut secara optimal, sehingga anak memiliki kecakapan hidup dan mampu menjalani realita dalam kehidupannya sesuai dengan potensi yang ada pada dirinya.

\section{MENGIDENTIFIKASI POTENSI ANAK}

Potensi akan nampak terlihat (teraktualisasikan) bila potensi di asah, distimulasi, dan dikembangkan oleh lingkungan sekitarnya. Sebaliknya potensi tidak akan nampak terlihat bila tidak diasah, distimulasi, dan dikembangkan oleh lingkungan sekitarnya. Hasil penelitian ilmiah menunjukkan bahwa anak yang banyak distimulasi oleh lingkungannya terbukti lebih cerdas dibanding dengan yang sedikit stimulasinya. Oleh karenanya peran lingkungan (orang tua, guru, teman sebaya, masyarakat sekitar) sangatlah besar untuk menstimulan munculnya berbagai potensi yang dimiliki. ${ }^{6}$

Potensi dalam dunia pendidikan akan memiliki peranan yang sangat berarti, karena dengan potensi seseorang dapat mengembangkan dirinya, dapat mengaktualisasikan dirinya. Aktualisasi diri merupakan tingkatan kebutuhan yang sudah masuk pada level tinggi -level meta-

6 Tugas perkembangan artinya tugas-tugas yang harus dicapai oleh peserta didik dalam setiap tahap perkembangannya. Perkembangan kemampuan manusia termasuk peserta didik diklasifikasikan pada: tahap bayi\&kanak-kanak, tahap anak-anak, tahap remaja, tahap setengah baya, tahap dewasa, dan tahap masa tua. 
oleh karenanya peran pendidik akan sangat besar artinya bila dia mampu menstimulasi berbagai potensi yang dimiliki oleh anak, sehingga potensi ini dapat digunakan untuk kepentingan-kepentingan tertentu dalam kehidupannya khususnya dalam dunia pendidikan. ${ }^{7}$ Bagi dunia pendidikan, pentingnya menggali potensi anak adalah dapat diketahui adanya perbedaan kemampuan anak. Konsekuensinya, para pendidik harus bisa memperlakukan anak yang berpotensi berbedabeda ini secara bijak.

Bila para pendidik telah melakukan berbagai stimulasi kepada anak dalam rangka menggali potensinya, maka sudah seyogianya apa yang sudah dilakukannya tersebut diuji. ${ }^{8}$ Tujuannya tiada lain adalah untuk mengetahui sampai sejauh mana potensi anak sudah terkembangkan, atau sampai sejauhmana kemajuan-kemajuan yang sudah dicapai anak dari stimulasi-stimulasi yang telah diberikan lingkungan (pendidik). Untuk kemudian dapat diambil langkah-langkah berikutnya.

Pengidentifikasian -atau istilah yang sering digunakan dalam bidang psikologi adalah diagnostik- terhadap potensi dapat dilakukan dengan mengenali keberbakatan anak dan kecenderungan minat jabatannya. ${ }^{9}$ Keberbakatan anak dapat dilihat dari tiga hal yaitu kemampuan umum yang tergolong di atas rata-rata (above average ability), kreativitas (creativity) tergolong tinggi, dan komitmen terhadap tugasnya (task commitment) yang tinggi atau sering disebut sebagai motivasi intrinsik.

8 Syah, Muhibbin, 2001. Psikologi Pendidikan dengan Pendekatan Baru. Bandung: Rosdakarya

9 Istilah cerdas (inteligensi) berbeda dengan IQ. Cerdas digunakan untuk melihat sejauh mana kemampuan seseorang dalam memecahkan masalah, sedangkan IQ digunakan untuk melihat bagaimana status seseorang dibandingkan dengan teman sebayanya. Untuk menentukan kecerdasan seseorang dapat dilakuan dengan cara mengukurnya dengan mengacu pada salah satu konsep yang ditawarkan para ahli seperti konsep multiple intelligence Gardner atau yang lainnya. Adapun untuk mengetahui IQ seseorang dapat dilakukan dengan tes IQ.

10 Nurul Iman (penterjemah), Motivation and PersonalityAbraham Maslow. 1984. Jakarta: PT Gramedia. Hal. 111
Adapun untuk mengetahui kecenderungan minat jabatan anak dapat dikenali dari tipe kepribadiannya.

\section{Kemampuan Umum}

Kemampuan umum anak dapat diketahui dengan melakukan tes inteligensi. Banyak ahli yang sudah mengungkapkan definisi tentang inteligensi, dari yang sangat sederhana sampai yang modern (lebih kompleks), di antaranya dikemukakan Wechsler. Wechsler mengungkapkan bahwa inteligensi adalah keseluruhan kemampuan individu untuk berpikir dan bertindak secara terarah, serta menyesuaikan diri dengan lingkungannya secara afektif. IQ adalah salah satu besaran pengukuran untuk panjang. Selain IQ, hasil tes inteligensi dapat juga dinyatakan dalam bentuk besaran-besaran lain seperti M.A. (mental age, usia mental), skor atau nilai standar, dan lain-lain. ${ }^{10}$ Thurstone mengemukakan bahwa kemampuan umum/kecerdasan seseorang dapat dilihat dari; Kemampuan verbal (verbal comprehension); Kelancaran kata (word fluency); Kemampuan mengenai angka (number); Kemampuan keruangan (space); Kemampuan ingatan (associative memory); Kecepatan persepsi (perceptual speed); dan Kemampuan menalar (induction, general reasoning). ${ }^{11}$

Senada dengan itu Munandar mengemukakan bahwa kemampuan umum anak merujuk pada beberapa indikator yaitu; Mudah menangkap pelajaran; Mudah mengingat kembali; Memiliki perbendaharaan kata yang luas; Penalaran tajam (berpikir logis, kritis, memahami hubungan sebab akibat); Daya konsentrasi baik; Menguasai banyak bahan tentang macam-macam topik; Senang dan sering membaca; Mampu mengungkapkan pikiran, perasaan, atau pendapat secara

11 Saifuddin Azwar, 2000. Tes Prestasi- Fungsi dan Pengembangan Pengukuran Prestasi Belajar. Jogjakarta: Pustaka Pelajar. Hal 13.

12 Depdiknas, 2004. Pedoman Diagnostik Potensi Peserta Didik. Jakarta, Proyek Peningkatan Mutu SLTP, hal. 18. 
lisan/tertulis dengan lancar dan jelas; Mampu mengamati secara cermat; Senang mempelajari kamus, peta, dan ensiklopedi; Cepat memecahkan masalah; Cepat menemukan kekeliruan atau kesalahan; Cepat menemukan asas dalam suatu uraian; Mampu membaca pada usia lebih muda; Daya abstraksi lebih tinggi; dan Selalu sibuk menangani berbagai hal. ${ }^{12}$

Dalam tes kemampuan umum (inteligensi), soal-soalnya mengukur hal-hal yang kurang dipengaruhi oleh pelajaran sekolah. ${ }^{13}$ Tes inteligensi memiliki jenis yang banyak. Ada tes inteligensi untuk anak, ada untuk orang dewasa. Ada yang pemberiannya secara individual, ada juga secara kelompok/klasikal. Ada yang lisan, ada juga yang tulisan. ${ }^{14}$ Pengukuran yang dilakukan oleh satu jenis alat tes inteligensi belum tentu akan memberikan hasil yang sama dengan menggunakan tes inteligensi yang lain. Ini disebabkan adanya kemungkinan landasan teori tentang inteligensi pada tes inteligensi yang satu berbeda dengan landasan teori tentang inteligensi pada tes inteligensi yang lain. Mungkin juga dasar pengukurannya berbeda-beda ${ }^{17}$. Secara keseluruhan tes inteligensi terdiri dari: tes inteligensi umum, tes inteligensi khusus, dan tes inteligensi diferensial. ${ }^{15}$

Tes inteligensi umum yang bertujuan memberikan gambaran tentang taraf inteligensi umum seseorang pada umumnya berdasarkan teori Spearmen. Spearmen mengungkapkan bahwa pelaksanaan setiap tugas kognitif (tugas yang membutuhkan pemikiran) membutuhkan kemampuan umum (general factor) dan kemampuan spesifik (spesific factor) untuk tugas tersebut. Menurutnya, pengukuran kemampuan umum yang terbaik adalah melalui persoalan-persoalan yang membutuhkan kemampuan menalar yang abstrak.

\footnotetext{
12 Saifuddin Azwar, Tes Prestasi- Fungsi..., hal. 55

${ }^{13}$ Saparinah Sadli, Inteligensi, Bakat,..., hal. 79.

14 Munandar, Utami, S.C., 1992. Mengembangkan Bakat dan Kreativitas Anak Sekolah. Jakarta: Gramedia, hal.33

${ }^{15}$ Saparinah Sadli, Inteligensi, Bakat,..., hal. 38.
}

Tes inteligensi diferensial yang memberikan keterangan tentang kemampuan di dalam berbagai faktor inteligensi pada umumnya di dasarkan pada teori Thurstone. Menurutnya faktor-faktor yang membentuk inteligensi meliputi: kemampuan verbal (verbal comprehension), kelancaran kata (word fluency), kemampuan mengenai angka (number), kemampuan keruangan (space), kemampuan ingatan (associative memory), kecepatan persepsi (perceptual speed), dan kemampuan menalar (induction, general reasoning).

Selain jenis tes sebagaimana dikemukakan di atas, berikut akan diberikan beberapa contoh tes yang sering digunakan;

1. Tes inteligensi dari Wechsler, yang mengukur taraf inteligensi umum. Tes inteligensi Wechsler adalah tes individual yang diberikan secara lisan dan dijawab secara lisan pula, serta dasar pengukurannya adalah Deviation IQ dengan nilai rata-rata $=100$ dan besar penyimpangan $=15$. Jenis tes ini diklasifikasikan lagi pada:

a. Khusus untuk anak-anak yang berusia 4 tahun sampai 6,5 tahun digunakan W.P.P.S.I. (Wechsler Preschool and Primary School intelligence).

b. Untuk anak-anak berusia 6,5 tahun sampai 16,5 tahun digunakan W. I. S. C (Wechsler Intelligence Scale for Children).

c. Untuk orang-orang dewasa digunakan W.B. (Wechsler Bellevue) dan W.A.I.S. (Wechsler Adult Intelligence Scale)

2. Tes C.F.I.T (Culture Fair Intelligence Test) dari Cattell, mengukur inteligensi umum, terdiri dari skala 1, skala 2, skala 3, untuk anak yang berusia 4 tahun sampai dengan orang dewasa. Jenis ini merupakan jenis tes inteligensi yang sifatnya nonverbal, yang bersifat kelompok dan tertulis. Dasar pengukurannya adalah Deviation IQ, dengan nilai rata-rata $=100$, dan besar penyimpangan $=16$.

Dengan tes inteligensi umum diperoleh suatu gambaran mengenai kecerdasan umum dari anak, sehingga pendidik memperoleh keterangan 
untuk dipergunakan lebih lanjut seperti untuk tujuan seleksi dan untuk tujuan diagnostik. ${ }^{16}$

Tujuan seleksi. Kenyataan dewasa ini menunjukkan masih terdapat perbedaan-perbedaan tingkat mutu atau kualitas serta fasilitas dari satu sekolah dengan sekolah yang lain. Keadaan ini menyebabkan ada sekolah favorit dan non favorit; sehingga ada sekolah yang dibanjiri peminat, sedang beberapa sekolah yang lain tidak dibanjiri oleh peminat. Kondisi ini menuntut untuk diadakan memilih peminat dari antara sekian banyak calon yang dianggap akan bisa mengikuti pendidikan dengan lancar. Dalam kondisi seperti ini diperlukan alat untuk menyaring calon-calon peminat seobjektif mungkin sesuai dengan tujuan yang diharapkan. Penggunaan nilai rapor atau pengukuran pada prestasi belajar jelas menimbulkan kesan yang kurang adil. Dalam kenyataannya proses-proses pendidikan dalam suatu sekolah secara menyeluruh berbeda dengan sekolah lain, sehingga hanya sekolah-sekolah tertentu saja yang selalu lebih berhasil. Selama perbedaan ini masih mencolok selama itu pula dirasakan kekurangadilan karena faktor kemampuan dan bakat khusus yang masih belum berfungsi kurang diperhatikan. Dengan tes inteligensi umum potensi yang ada pada peserta didik, ikut diperhitungkan. Inilah keunggulan tes inteligensi umum dibanding tes prestasi sekolah, bila penggunaannya betul-betul terlaksana dengan teliti dan objektif.

Tujuan diagnostik. Dengan adanya perbedaan individual, maka terdapat perbedaanperbedaan taraf kecerdasan umum. Ada yang sangat tinggi, tinggi, sedang, rendah, dan kurang atau klasifikasi lain yang pada dasarnya menunjukkan adanya perbedaan taraf atau batas yang dapat dicapai oleh kemampuan yang dimiliki peserta didik. Dengan tes inteligensi umum dapat diketahui apakah kesulitan-kesulitan belajar yang dialami peserta didik disebabkan oleh terbatasnya taraf inteligensi yang dimiliki sehingga ia tidak mungkin lagi mengikuti proses belajar yang sama dengan irama dan tempo belajar peserta didik lain.

Dari hasil tes inteligensi umum yang dilakukan terhadap anak akan dapat ditentukan apakah ada faktor lain yang menyebabkan timbulnya kesulitan belajar atau rendahnya prestasi belajar yang bukan disebabkan oleh keadaan atau kualitas inteligensinya, melainkan oleh hal lain yang harus diteliti lebih lanjut.

Mengetahui taraf inteligensi umum anak secara benar (objektif) perlu bagi orang tua dan para pendidik agar tidak terjadi pemaksaan yang berlebihan terhadap anak untuk dapat mempelajari sesuatu dan menuntut prestasi di atas kemampuan yang dapat dijangkaunya. Keadaan ini seringkali menimbulkan kesulitan sehingga perlu penanganan sistematis dalam rangka penanaman pengertianpengertian baru pada orang tua. Suatu hal yang wajar kalau orang tua menghendaki agar anaknya dapat mengikuti pendidikan dengan sebaik-baiknya dan kalau bisa setinggi-tingginya agar anak bisa mandiri. Wajar pula kalau orang tua menciptakan suasana dan mengadakan fasilitas sebaik-baiknya agar anak bisa mengembangkan diri. Oleh karenanya, untuk kepentingan-kepentingan tersebut dasar pegangan melalui penilaian psikologis termasuk tes inteligensi umum seringkali sangat membantu.

\section{$\underline{\text { Kreativitas }}$}

Cara kedua untuk mengetahui keberbakatan anak dapat dilihat dari kreativitasnya ${ }^{21}$. Kreativitas merupakan kemampuan untuk membuat kombinasi baru berdasarkan data, informasi, atau unsur-unsur yang ada. Kreativitas juga merupakan kemampuan -berdasarkan data atau informasi yang tersediamenemukan banyak kemungkinan jawaban terhadap suatu masalah, dimana penekanannya adalah pada kuantitas, ketepatgunaan, dan
16 Ibid., hal. 80. 
keragaman jawaban. ${ }^{17}$ Tentu saja jawaban-jawaban itu harus sesuai dengan masalahnya. Jadi tidak semata-mata banyaknya jawaban yang dapat diberikan yang menentukan kreativitas seseorang, tetapi juga kualitas atau mutu dari jawabannya. Secara operasional kreativitas dapat dirumuskan sebagai kemampuan yang mencerminkan kelancaran, keluwesan (fleksibilitas), dan orosinalitas dalam berpikir serta kemampuan untuk mengelaborasi (mengembangkan, memperkaya, memperinci) suatu gagasan.

Secara detail, kreativitas anak dapat dilihat dari beberapa indikator; Memiliki rasa ingin tahu yang besar; Sering mengajukan pertanyaan yang berbobot; Memberikan banyak gagasan dan usul terhadap suatu masalah; Mampu menyatakan pendapat secara spontan dan tidak malu-malu; Mempunyai/menghargai rasa keindahan; Mempunyai pendapat sendiri dan dapat mengungkapkannya, tidak mudah terpengaruh orang lain; Memiliki rasa humor tinggi; Mempunyai daya imajinasi yang kuat; Mempunyai daya imajinasi yang kuat; Mempunyai daya imajinasi yang kuat; Dapat bekerja sendiri; Senang mencoba hal-hal baru; Mampu mengembangkan atau merinci suatu gagasan (kemampuan elaborasi). ${ }^{18}$

Berdasarkan indikator di atas jelas bahwa kreativitas dapat terwujud di mana saja dan oleh siapa saja, tidak bergantung pada usia, jenis kelamin, keadaan sosial ekonomi atau tingkat pendidikan tertentu. Kreativitas dimiliki oleh semua orang tanpa pandang bulu. Lebih penting lagi adalah bahwa kreativitas bila dikaitkan dengan masalah pendidikan, dapat ditingkatkan, dan karenanya perlu dipupuk sejak dini.

\section{Motivasi}

Cara ketiga untuk memahami keberbakatan anak adalah dapat dilihat dari komitmen tugas anak atau sering disebut sebagai motivasi intrinsik anak. Motivasi intrinsik dapat diartikan sebagai dorongan kuat yang bersumber dari dalam diri anak untuk melakukan sesuatu (belajar). Anak mau belajar karena ia betul-betul memiliki dorongan kuat dari dalam dirinya untuk belajar, bukan karena tergiur oleh iming-iming atau hadiah dari orang tua atau dari gurunya. Bila anak mau belajar karena tergiur oleh hadiah yang akan diberikan orang tuanya maka motivasi yang dimiliki anak disebut sebagai motivasi ekstrinsik. ${ }^{19}$ Indikator dari motivasi (intrinsik) anak meliputi; Tekun menghadapi tugas (dapat bekerja terus menerus dalam waktu yang lama, tidak berhenti sampai selesai); Ulet menghadapi kesulitan (tidak lekas putus asa); Tidak memerlukan dorongan dari luar untuk berprestasi; Ingin mendalami bahan/bidang pengetahuan yang diberikan; Selalu berusaha berprestasi sebaik mungkin (tidak cepat puas dengan prestasinya); Menunjukkan minat terhadap macam-macam masalah "orang dewasa" (misalnya terhadap pembangunan, korupsi, keadilan, dan sebagainya); Senang dan rajin belajar, penuh semangat, cepat bosan dengan tugas-tugas rutin, dapat mempertahankan pendapat-pendapatnya (kalau sudah yakin akan sesuatu, tidak mudah melepaskan hal yang diyakini tersebut); Mengejar tujuan-tujuan jangka panjang (dapat menunda pemuasan kebutuhan sesaat yang ingin dicapai kemudian); dan Senang mencari dan memecahkan soal-soal. ${ }^{20}$

Berdasarkan indikator-indikator di atas, maka sebagian potensi anak dapat diketahui. Pendidik dapat mengembangkan alat tes motivasi untuk mengetahui motivasi anak berdasarkan pada indikator di atas.

\section{$\underline{\text { Tes Kepribadian }}$}

Cara lain untuk mengidentifikasi potensi anak adalah berdasarkan kecenderungan minat

\footnotetext{
${ }^{17}$ Ibid. hal. 112

${ }^{18}$ Ibid. hal. 88
}

\footnotetext{
${ }^{19}$ Ibid. hal. 85

${ }^{20}$ Ibid.
} 
jabatannya yang dapat dikenali dari tipe kepribadiannya. Berdasar tes kepribadian maka diperoleh data yang bersifat kualitatif-deskriptif. Penggunaan tes ini sering tidak dilakukan secara tersendiri, melainkan bersama-sama dengan tes-tes psikologi lainnya. Kesulitan dan hambatan dalam prestasi belajar di sekolah tidak selalu disebabkan oleh hal-hal yang berhubungan dengan aspek inteligensi saja, melainkan dapat pula oleh hal-hal lainnya yang berkaitan dengan ciri-ciri kepribadian anak, termasuk cara-cara dan kebiasaaan belajarnya. Berdasar tes kepribadian akan diperoleh deskripsi tentang ciri-ciri kepribadian anak sebagai bahan untuk menentukan sumber timbulnya kesulitan belajar. $^{21}$

Gangguan emosi merupakan hal yang sering menghambat kemantapan belajar anak baik di sekolah maupun di rumah. Melalui wawancara dan pengamatan seringkali bisa diperoleh data-data yang penting, tetapi seringkali pula harus dilakukan tes kepribadian untuk bisa memancing hal-hal yang lebih mendalam dan mendasar pada kepribadian anak. Dengan mengetahui adanya kepribadiankepribadian tertentu pada anak yang dapat menghambat prestasi belajarnya, maka akan dapat ditentukan langkah-langkah lebih lanjut untuk mengatasinya.

Jenis tes kepribadian sangat banyak, setiap psikolog mempunyai kesenangan untuk mempergunakan tes-tes kepribadian berdasar yang paling dikuasai dan dirasakan dapat dipergunakan secara produktif, sesuai dengan tujuan pemeriksaan.

Bila berdasarkan tes kepribadian diperoleh adanya masalah belajar pada anak, maka diperlukan kerja sama dengan pihak sekolah, pendidik, wali kelas, kepala sekolah dan tidak terkecuali juga pihak orang tua atau keluarganya untuk mengatasinya. Dari identifikasi kepribadian anak menunjukkan bahwa tidak semua jabatan cocok untuk semua orang. Setiap tipe kepribadian tertentu mempunyai

${ }^{21}$ Depdiknas..., hal. 18 kecenderungan terhadap minat jabatan tertentu pula.

Tipe kepribadian dan ciri-cirinya menurut Holland meliputi beberapa aspek.

Realistik (realistic) yaitu kecenderungan untuk bersikap apa adanya atau realistik. Ciricirinya: rapi, terus terang, keras kepala, tidak suka berkhayal, tidak suka kerja keras.

Penyeilidik (investigative) yaitu kecenderungan sebagai penyelidik. Ciri-cirinya: analitis, hati-hati, kritis, suka yang rumit, rasa ingin tahu besar.

Seni (artistic) yaitu kecenderungan menyukai seni. Ciri-cirinya: tidak teratur, emosi, idealis, imajinatif, terbuka.

Sosial (social) yaitu kecenderungan suka terhadap kegaiatn-kegiatan yang bersifat sosial. Ciricirinya melakukan kerjasama, sabar, bersahabat, rendah hati, menolong, dan hangat.

Suka usaha (enterprising) yaitu kecenderungan menyukai bidang usaha. Ciri-cirinya: ambisius, energik, optimis, percaya diri, dan suka berbicara.

Tidak mau berubah (conventional) yaitu kecenderungan untuk mempertahankan hal-hal yang sudah ada, enggan terhadap perubahan. Ciricirinya: hati-hati, bertahan, kaku, tertutup, patuh, konsisten.

Berdasarkan ciri-ciri itulah seorang anak dapat diketahuitipe kepribadiannya. Selanjutnya potensi anak dapat diketahui dalam bidang apa dan kemana ia akan diarahkan. ${ }^{22}$

Adapun cara pengumpulan informasi untuk mengidentifikasi anak berbakat dapat dilakukan dengan dua cara yaitu dengan menggunakan data objektif dan data subjektif. ${ }^{23}$ Identifikasi melalui penggunaan data objektif diperoleh melalui antara lain: skor tes inteligensi individual, skor tes inteligensi kelompok, skor tes akademik, dan skor

22 J.P Guilford, 1971. The Nature of Human Intelligence, New York: Mc Graw Hill, hal. 137

23 Munandar Utami, S.C., Mengembangkan Bakat..., hal. 51. 
tes kreativitas. Tes inteligensi individual, kelompok dan tes kreativitas, pihak sekolah dapat melakukannya dengan cara menghubungi Fakultas Psikologi atau Kantor Konsultan Psikologi yang ada di daerahnya masing-masing. Sedangkan untuk mendapatkan skor tes akademik pihak sekolah dapat melakukannya sendiri. Skor tes akademik yang dilakukan oleh sekolah dilihat dari nilai-nilai mata pelajaran bahasa Indonesia, bahasa Inggris, matematika, pengetahuan sosial, dan sains (fisika, biologi, dan kimia).

Adapun identifikasi melalui penggunaan data subjektif diperoleh dari: ceklis perilaku, nominasi oleh guru, nominasi oleh orang tua, nominasi oleh teman sebaya, dan nominasi oleh diri sendiri. $^{24}$ Pihak sekolah bisa mendapatkan data subjektif ini dengan mengembangkan sendiri yang mengacu pada konsepsi dan ciri keberbakatan yang terkait.

\section{KESIMPULAN}

Setiap manusia memiliki segudang potensi yang merupakan sebuah anugerah dari Tuhan. Potensi-potensi ini dapat berwujud inteligensi (kecerdasan), bakat, prestasi, kepribadian, dan sebagainya. Semua ini butuh stimulasi dari lingkungan sekitarnya agar potensi-potensi yang dimiliki oleh anak dapat teraktualisaikan ke dalam kehidupan nyata. Dengan pemberian stimulasi yang sangat beragam dari lingkungan pendidikan maka potensi anak dapat dan akan terasah, yang pada akhirnya dapat digali dengan menggunakan alat-alat atau cara-cara tertentu seperti tes inteligensi, tes bakat, dan tes kepribadian.

${ }^{24}$ Dalam perspektif kognitif motivasi intrinsik lebih signifikan bila dibandingkan dengan motivasi ekstrinsik karena motvasi intrinsik sifatnya lebih murni dan lebih langgeng serta tidak bergantung pada dorongan atau pengaruh orang lain (Muhibbin Syah, 2001. Psikologi Pendidikan, hal. 132)

\section{DAFTAR KEPUSTAKAAN}

Depdiknas, 2004. Pedoman Diagnostik Potensi Peserta Didik. Jakarta, Proyek Peningkatan Mutu SLTP.

Depdiknas, 2004. Tahap-tahap Perkembangan Peserta Didik, dalam Pedoman diagnostik Potensi Peserta Didik. Ditjen Dikdas Direktorat Pendidikan Lanjutan pertama.

Hand out mata kuliah Psikologi Inteligensi pada Program Pasca Sarjana Program Studi Psikologi UGM oleh Yapsir Gandhi Wirawan J.P Guilford, 1971. The Nature of Human Intelligence, New York: Mc Graw Hill.

Munandar, Utami, S.C., 1992. Mengembangkan Bakat dan Kreativitas Anak Sekolah. Jakarta: Gramedia.

Monks dkk., 1996. Psikologi Perkembangan Pengantar dalam Berbagai Pengembangannya. Jogjakarta: Gadjah Mada University Press.

Nurul Iman (penterjemah), Motivation and PersonalityAbraham Maslow. 1984. Jakarta: PT Gramedia.

Saparinah Sadli (editor), 1986. Inteligensi, Bakat, dan Test IQ. Cetakan I. Jakarta: Gaya Favorit Press.

Santrock, 1997, Life Span Development, TT.

Saifuddin Azwar, 2000. Tes Prestasi- Fungsi dan Pengembangan Pengukuran Prestasi Belajar. Jogjakarta: Pustaka Pelajar.

Syah, Muhibbin, 2001. Psikologi Pendidikan dengan Pendekatan Baru. Bandung: Rosdakarya 